\title{
Public Open Space as Urban Architecture: Design and Public Life
}

\author{
Achmad Delianur Nasution ${ }^{\mathrm{a}^{*}}$, Wahyuni Zahraha \\ ${ }^{a}$ Department of Architecture, Faculty of Engineering, Universitas Sumatera Utara, Medan 20154, Indonesia \\ *Corresponding author. Tel.: +62 82163152525; fax: +62 618213250 . \\ E-mail address: aan.nasution@gmail.com
}

\begin{abstract}
Public open space (POS) does not become an adequate priority in urban planning and design in developing countries, including Indonesia. The cities are almost 'full of buildings' and 'less of POS.' Meanwhile, many studies show that the POS has a significant effect on citizens' quality of life. By this situation, the research means to explore the quality of public open space in relation to its utilization. The study observed POS in several small towns in North Sumatra Province, where new urbanized area had been rising by autonomy regulation. A visual survey was carried out to record, map and identify the quality of the public open spaces. Besides, the visitors were interviewed to get their perception of the quality of POS. The investigation indicates that almost of public life did not always equal with the design of the POS. Almost POS have no pedestrian linkage to make it connect with the other urban space. Thus, the majority of POS was alienated with the other part of cities.There was no integration with public transport, too. The facilities were less of maintenance. However, the community kept coming to the place and doing many activities. The respondents perceived the POS as quite good, but not good enough. Still, they mostly believed that the POS have a real impact on their quality of life.
\end{abstract}

Keywords: open space; urban architecture; public life; quality of life; Sumatra Utara

\section{Introduction}

\subsection{Background}

One of the essential elements of urban design is public open space (POS). The POS can be a square, park, garden, circulation path, marketplace or space between buildings. Many studies argue that the areas give a positive contribution to community quality of life, even when they have to compete with the higher design quality of privatized public space (Nasution \& Zahrah, 2012). The past research about public open space in Medan (the capital city of Sumatera Utara province) shows that many public open spaces have a poor quality of design, but the community keeps utilize the space intensively (Nasution \& Zahrah, 2014). Meanwhile, the process of urbanization does not only occur in capital city Medan, but also in the other smaller towns in Sumatra Utara Province. In line with the implementation of autonomy regulation in Indonesia, some new urbanized areas grow. Although on a smaller scale, the characteristic of small towns in Sumatra Utara province is similar with Medan, such as the increasing of commercial districts with high-density buildings. As the urbanized area of many regencies (Kabupaten) in Sumatera Utara province increase, it is necessary to study the POS there. How is the design quality? How the communities utilize it? How is their perception about the POS? The research can give a description how are the design of public open space, particularly in the developing country in relation to its utilization and role for community's life. 


\subsection{Objective}

The research means to explore the design of POS in some small towns in Sumatera Utara province in relation to its utilization. The result can contribute to developing design aspect of public open space in the urban area that responds to the local community needs.

\section{The design of public open space}

Some studies about POS indicate that physical quality influences the level and way of the utilization of the space. Some scholars explore the issues of accessibility, facility, and natural elements.

\subsection{Accessibility}

Many studies about the accessibility of POS argue that the linkage and pedestrian path is a "must have" design aspect. It is characterized by the easy access and movement system (Carr, Francis, Rivlin, \& Stone, 1992; Danisworo, 1988; Project for Public Spaces., 2000; Rivlin, 1994); a clear circulation path and linkage (CABE \& DETR, 2001; GEHL Architects, 2002; Project for Public Spaces., 2000); the integration of transportation modes and land use, and the landmark that can help people to identify the orientation point (CABE \& DETR, 2001); distance, public transportation mode and parking lot (Curson, Evans, \& Bohrer, 1995). The availability of pedestrian path is more necessary to get easy access to POS, compares to the motor vehicles (Carr et al., 1992). However, many city plans in Indonesia do not pay attention for the pedestrian. The urban space is a car-oriented design. It gives more space for vehicles than pedestrian. For example, in Magelang, the POS is hard to be accessed, not comfort, not attractive and no supporting facilities (Arifady, 2001). According to this condition, it is necessary to look out the aspects of POS accessibility in Indonesia.

\subsection{Facility}

The facility is an important part of the design feature of POS. It is important to plan an open space that ensures the comfort of a place and the activity with a human scale factor (Ashihara, 1981; Shirvani, 1985). Some necessary facilities are sitting area (Avila, 2001; Carr et al., 1992; GEHL Architects, 2002), cafe, restaurant and shops with good lightings (GEHL Architects, 2002). In Medan, Sumatra Utara, there are some facilities for people needs, such as prayer room, public toilet, children playground, parking lot, podium (pendopo), bench/outdoor seating, sport area (for basketball, volleyball, badminton), garden, trees, and street vendor (Nasution \& Zahrah, 2014). Pendopo and prayer room are some facilities that only found in Indonesia. The facilities is a respond to local people that mostly Moslems. The pendopo is always found because many POS is the squares that functioned as official National Ceremony. The study about the facility in POS design can contribute to improving the quality of POS, particularly to identify local people needs.

\subsection{Natural elements}

One of the natural elements in public open space is the green area. The greenery has a lot of useful purposes that is related to function, aesthetics, and weather function. These vegetations will affect the atmosphere surrounding, changing the temperature and humidity (Lakitan, 2002; Martopo, Fandeli, Herlian, \& Purwanto, 1995). Area covered by trees will have the higher humidity than the 'open' lands (sand, gravel, and its kind)(Laurie, 1986; Pudjiharta, 1980). This uncovered zone tends to have a higher temperature and lower humidity. The trees should be planted in pedestrians and open space to get the best advantage (Whyte, 1980). 


\subsection{Public life}

Public life relates to the public activity that done by the community in public spaces (GEHL Architects, 2002; Whyte, 1980). The successful public space accommodates various activity of various ages and class of people (CABE \& DETR, 2001; Rivlin, 1994; Whyte, 1980). The activities in public spaces can be an optional or a necessary activity. However, the more optional activities, the more successful the public space. This condition is supported by a high-quality design (GEHL Architects, 2002). In Indonesian cities, the public open space is not always designed by professional, such as architect or landscape architects. In this condition, it is necessary to study how the public life goes on in POS to improve an adequate design that fit local people needs.

\section{Methodology}

\subsection{Study area}

This study is located in the POS of seven small towns in the province of Sumatera Utara, Indonesia. They are POS of Kota Salak, Raya, Kotapinang, Sidikalang, Panyabungan, Rantauprapat, and Aek Kanopan. Among these towns, Rantauparapat is the only oldest district. The others are the new urban area as the consequence of autonomy regulation.

\subsection{Respondents}

Respondents in this research were people that visited POS; 376 visitors agreed to participate in the survey of 800 questionnaires. Numbers of respondents were varying depending on the amount of visitors that were active in the POS.

\subsection{Data collecting}

This study collected two types of data; the condition in POS and the perception of visitors. The situation of POS was recorded through the field survey. The aspects of design recorded were accessibility, facility, and natural elements. The activities were represented in a behavioral map, so it could give information about its distribution in every zone of public open space. These data were collected in the weekend in several timing-groups during the morning, evening, and night. The perceptions of users were collected through questionnaires. The visitors gave the level of their satisfaction with the aspects of POS with five points Likert Scale, starting from very unsatisfied (1) to very satisfied (5).

\subsection{Data analysis}

The research is a descriptive, explorative study. The data analysis uses descriptive statistic to describe the trend of the intensity of utilization and the variation of the activities. The quality of design is identified by explaining some design aspects, such as accessibility, facility, and natural elements, based on the relevant literature. The perception of some aspects of POS design and quality of life uses the mean score of satisfaction level. 


\section{Result and Discussioon}

\subsection{Respondents characteristics}

The majority of respondents were the local residents. The proportion of males and females were varying in every location. However, in Aek Kanopan and Sidikalang, the respondents were more likely to be males. The visitors were balanced between teenagers and the older age group. Most of the respondents were students or civil servants. Since there was a difference of age in every location, the respondents consisted of those who were married and single. Most of the interviewees were the low-income people (less than 2.5 million IDR per months). More than half of respondents had their own motorcycle (Table 1).

Table 1. Respondents characteristics.

\begin{tabular}{|c|c|c|c|c|c|c|c|c|}
\hline \multirow[b]{2}{*}{ Variable } & \multicolumn{8}{|c|}{ Open Space } \\
\hline & $\begin{array}{c}\text { Aek } \\
\text { kanopan }\end{array}$ & $\begin{array}{c}\text { Kota } \\
\text { pinang }\end{array}$ & $\begin{array}{l}\text { Panya } \\
\text { bungan }\end{array}$ & $\begin{array}{l}\text { Rantau } \\
\text { prapat }\end{array}$ & Raya & Salak & $\begin{array}{c}\text { Sidi } \\
\text { kalang }\end{array}$ & Average \\
\hline $\begin{array}{l}\text { Total Respondents } \\
\text { Residential status }\end{array}$ & 89 & 81 & 30 & 98 & 5 & 39 & 34 & 53,7 \\
\hline Local residents & 82 & 69,1 & 53,3 & 77,6 & 60 & 15,4 & 73,5 & 61,6 \\
\hline Temporary stay & 7,9 & 16 & 16,7 & 9,2 & 40 & 82,1 & 11,8 & 26,2 \\
\hline Visitors & 1,01 & 14,8 & 30 & 13,3 & 0 & 2,6 & 14,7 & 10,9 \\
\hline \multicolumn{9}{|l|}{ Gender } \\
\hline Woman & 62,9 & 43,2 & 53,3 & 50 & 0 & 5,1 & 79,4 & 42,0 \\
\hline Man & 37,1 & 56,8 & 46,7 & 50 & 100 & 94,9 & 20,6 & 58,0 \\
\hline Age & $\begin{array}{c}41-50= \\
18,0 \%\end{array}$ & $\begin{array}{l}16-20= \\
29,6 \%\end{array}$ & $\begin{array}{l}26-30= \\
33,3 \%\end{array}$ & $\begin{array}{l}31-35= \\
22,4 \%\end{array}$ & $\begin{array}{c}21-25 \& \\
36-40= \\
40,0 \%\end{array}$ & $\begin{array}{l}16-20= \\
74,4 \%\end{array}$ & $\begin{array}{l}16-20= \\
38,2 \%\end{array}$ & \\
\hline Job & $\begin{array}{l}\text { Others } \\
40,4 \%\end{array}$ & $\begin{array}{c}\text { Student/ } \\
\text { College } \\
\text { student } \\
39,5 \%\end{array}$ & $\begin{array}{l}\text { Others } \\
36,7 \%\end{array}$ & $\begin{array}{c}\text { Student/ } \\
\text { College } \\
\text { student } \\
26,5 \%\end{array}$ & $\begin{array}{c}\text { Civil } \\
\text { servants } \\
\& \text { self- } \\
\text { working } \\
40 \%\end{array}$ & $\begin{array}{c}\text { Civil } \\
\text { servants } \\
82,1 \%\end{array}$ & $\begin{array}{c}\text { Student/ } \\
\text { College } \\
\text { student } \\
70,6 \%\end{array}$ & \\
\hline \multicolumn{9}{|l|}{ Marital status } \\
\hline Married & 60,7 & 42 & 46,7 & 61,2 & 0 & 2,6 & 23,5 & 338 \\
\hline Single & 3,03 & 58 & 43,3 & 38,8 & 100 & 97,4 & 76,5 & 506 \\
\hline $\begin{array}{l}\text { Earings permonth } \\
\text { (Rp) }\end{array}$ & $\begin{array}{c}<2,5 \\
\text { millions } \\
68,5 \%\end{array}$ & $\begin{array}{c}<2,5 \\
\text { millions } \\
74,1 \%\end{array}$ & $\begin{array}{c}<2,5 \\
\text { millions } \\
60 \%\end{array}$ & $\begin{array}{c}<2,5 \\
\text { millions } \\
53,1 \%\end{array}$ & $\begin{array}{c}2,5-5 \\
\text { millions } \\
80 \%\end{array}$ & $\begin{array}{c}<2,5 \\
\text { millions } \\
97,4 \%\end{array}$ & $\begin{array}{c}<2,5 \\
\text { millions } \\
76,5 \%\end{array}$ & \\
\hline
\end{tabular}

\subsection{The design of POS}

The POS in this study were the squares. Some of them were similar to the square in Medan; there was a part of the place that was designed like a park, with seating area, sports facility, children playground, and flower garden. Some other squares were less of facilities. However, all the squares had a same main function; it was the field that used for official National Ceremony, such as Independence Day of Indonesia Republic. 


\section{a. Accessibility}

The accessibility in all open space area in this study was relatively good when viewed from the aspects of distance and how easy it was accessed (Carr et al., 1992; Danisworo, 1988; Project for Public Spaces., 2000; Rivlin, 1994), public transportation and traffic (Curson et al., 1995). There were the gate and signage in every open space with various design. These elements gave clear directions to visitors when entering a park (CABE \& DETR, 2001). Respondents gave a quite good score for these accessibility aspects (score more than 3 ), but the score did not reach 4 (satisfied, Table 2). All open spaces were not far from residential area. Thus, it could be accessed easily by walking or vehicles. However, almost all visitors in all location did not walk, most of them used their motorcycle, even the distance from their home to the POS was in the range of footwalk. There was a pedestrian path, but no linkage or networking with the other places and paths of town. However, its accessibility was quite easy because of its light traffic. It was different with the condition in Medan city that some POS were surrounded by heavy traffic. It made the POS "an island that needs to be crossed" (Nasution \& Zahrah, 2014).

Table 2. Level of satisfaction with accessibility

\begin{tabular}{|c|c|c|c|c|c|c|c|c|}
\hline \multirow{2}{*}{ Variable } & \multicolumn{8}{|c|}{ Open space } \\
\hline & $\begin{array}{c}\text { Aek } \\
\text { kanopan }\end{array}$ & $\begin{array}{c}\text { Kota } \\
\text { pinang }\end{array}$ & $\begin{array}{c}\text { Panya } \\
\text { bungan }\end{array}$ & $\begin{array}{l}\text { Rantau } \\
\text { prapat }\end{array}$ & Raya & Salak & $\begin{array}{c}\text { Sidi } \\
\text { kalang }\end{array}$ & Average \\
\hline Distance from park to home & 3,07 & 3,56 & 2,97 & 3,66 & 4,40 & 4,36 & 3,56 & 3,65 \\
\hline Entrance facilities to POS & 3,93 & 3,81 & 3,27 & 3,97 & 4,60 & 4,62 & 4,24 & 4,06 \\
\hline Transportation facilities to POS & 3,54 & 3,69 & 2,97 & 3,64 & 4,40 & 4,46 & 3,76 & 3,78 \\
\hline Traffic facilities around POS & 3,66 & 3,84 & 3,23 & 3,73 & 4,80 & 4,64 & 3,88 & 3,97 \\
\hline Average & 3,55 & 3,73 & 3,11 & 3,75 & 4,55 & 4,52 & 3,86 & 3,87 \\
\hline
\end{tabular}

The survey indicates that all good design pedestrian in public space did not relate to its level of usage. The great and nice pedestrian path can be found in Raya and Salak, but these squares were less of visitors. Otherwise, in Aek Kanopan and Kota Pinang, the pedestrian path had a poor design, but people used it actively. By this situation, people perceived the pedestrian path as quite good, except Panyabungan (Table 2). The facts show that there is a different need between the community in Sumatra Utara and the cities in the developed countries. Many studies argue that a high quality of pedestrian path is a 'must have' for a high-quality public space (Carr et al., 1992; Project for Public Spaces., 2000). The researchers in the developed country found a significant correlation between the pedestrian linkage and level of usage in a park (Project for Public Spaces., 2000; Sugiyama, Francis, Middleton, Owen, \& Giles-Corti, 2010), but not in this study. The community was almost 'the motor-cycle-dependency" (Table 3 ), so it looked like that they did not need a pedestrian path. The fact relates to the current urban physical quality in Indonesia; that does not offer a pedestrian path for people. On the other hand, the selling of motorcycle becomes easier and cheaper. It makes the community leave walking tradition of the rural population. This reality is similar to the other small towns in Sumatera Utara (Nasution \& Zahrah, 2015) and Medan (Nasution \& Zahrah, 2014) and very contrast when compared to open space in developed countries. 
Table 3. Vehicle ownership, distance and types of transportation used to POS

\begin{tabular}{|c|c|c|c|c|c|c|c|}
\hline \multirow{2}{*}{ Question } & \multicolumn{7}{|c|}{ Public open space } \\
\hline & $\begin{array}{c}\text { Aek } \\
\text { kanopan }\end{array}$ & $\begin{array}{c}\text { Kota } \\
\text { pinang }\end{array}$ & $\begin{array}{l}\text { Panya } \\
\text { bungan }\end{array}$ & R. Parapat & Raya & Salak & $\begin{array}{c}\text { Sidi } \\
\text { kalang }\end{array}$ \\
\hline $\begin{array}{l}\text { Do you have your } \\
\text { own vehicle? }\end{array}$ & $\begin{array}{c}\text { Yes, } \\
\text { mot.cycle } \\
69,7 \%\end{array}$ & $\begin{array}{c}\text { Yes, } \\
\text { mot.cycle } \\
64,2 \%\end{array}$ & No $60 \%$ & $\begin{array}{c}\text { Yes, } \\
\text { mot.cycle } \\
65,3 \%\end{array}$ & $\begin{array}{c}\text { Yes, } \\
\text { mot.cycle } \\
100 \%\end{array}$ & $\begin{array}{c}\text { Yes, } \\
\text { mot.cycle } \\
92,3 \%\end{array}$ & No $67,6 \%$ \\
\hline Going to park by & $\begin{array}{c}\text { Mot.cycle } \\
87,6 \%\end{array}$ & $\begin{array}{c}\text { Mot.cycle } \\
75,3 \%\end{array}$ & $\begin{array}{c}\text { Mot.cycle } \\
36,7 \%\end{array}$ & $\begin{array}{c}\text { Mot.cycle } \\
66,3 \%\end{array}$ & $\begin{array}{l}\text { Mot.cycle } \\
\text { r } 100 \%\end{array}$ & $\begin{array}{c}\text { Mot.cycle } \\
94,9 \%\end{array}$ & $\begin{array}{c}\text { Motcycle } \\
\& \\
\text { walking } \\
35,3 \%\end{array}$ \\
\hline $\begin{array}{l}\text { Distance from } \\
\text { home to the park }\end{array}$ & $\begin{array}{l}1-3 \mathrm{~km} \\
37,1 \%\end{array}$ & $\begin{array}{c}\text { Less than } \\
500 \mathrm{~m} \\
23,8 \%\end{array}$ & $\begin{array}{c}\text { Less than } \\
500 \mathrm{~m} \\
30 \%\end{array}$ & $\begin{array}{c}500 \mathrm{~m}- \\
1 \mathrm{~km} \\
28,6 \%\end{array}$ & $\begin{array}{c}500 \mathrm{~m}- \\
1 \mathrm{~km} \mathrm{\&}> \\
5 \mathrm{~km} 40 \%\end{array}$ & $\begin{array}{c}500 \mathrm{~m}- \\
1 \mathrm{~km} \\
87,2 \%\end{array}$ & $\begin{array}{c}500 \mathrm{~m}- \\
1 \mathrm{~km} \\
38,2 \%\end{array}$ \\
\hline
\end{tabular}

Table 4. Available Facilities in POS

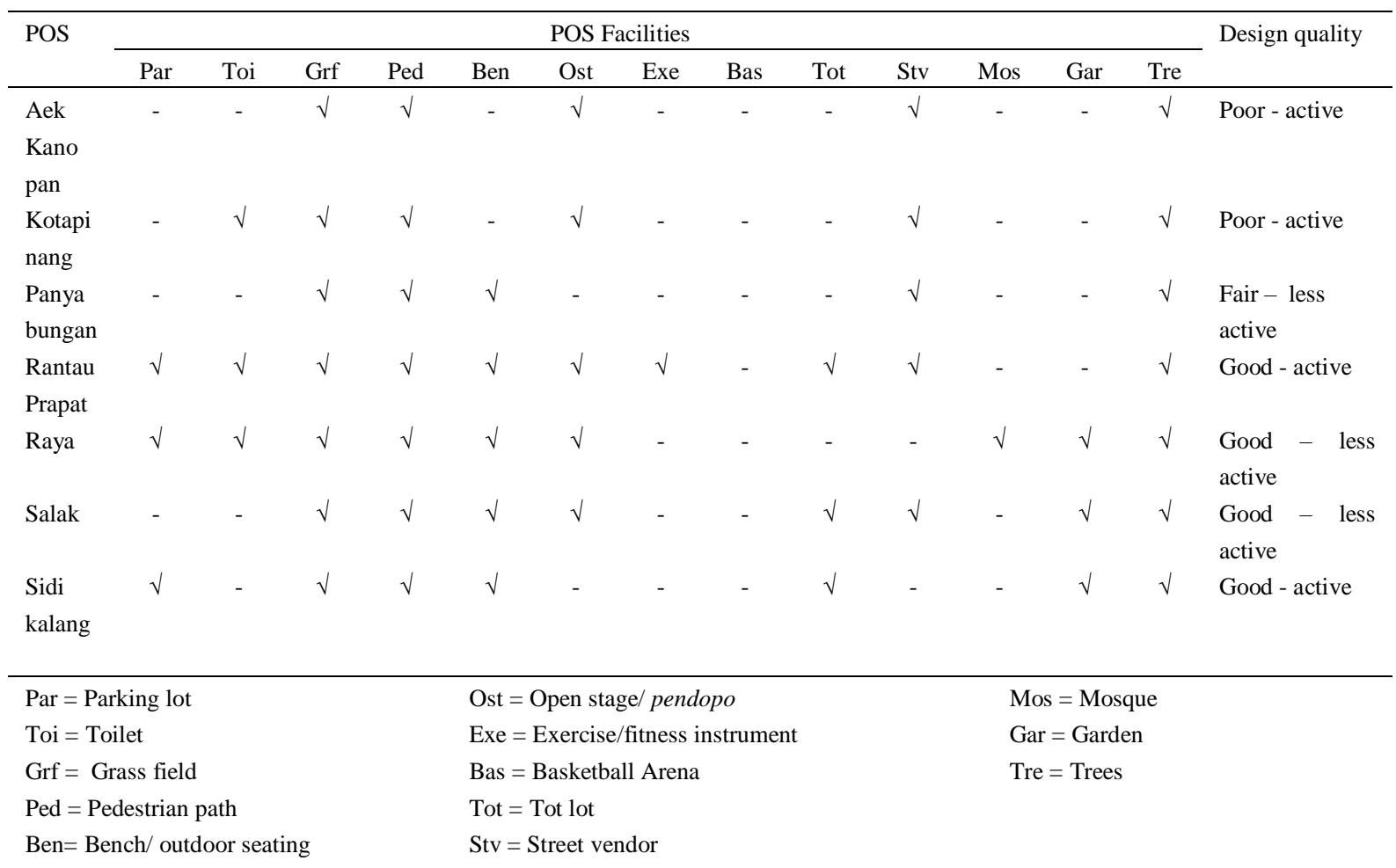

\section{b. Facility}

The facility is one of design aspect that guarantees visitors to do activity much easier and comfortable. The survey indicated that facilities available in all open space were grass field, pedestrian path, and various trees. Sitting area, food vendors were found in almost all POS, while toilet, park, parking area, and children playgrounds were only found in a half of them (Table 4). Bench and sitting area in some POS were high quality, but some of them not. The recreation and playing area were found in almost all POS but were not always supported by an adequate facility. The condition is different with the POS of developed country as studied by PPS (Project for Public Spaces., 2000) 
that mostly have a good quality. The facilities in Aek Kanopan square, for example, with a minimum installation, still had a lot of visitors. Otherwise was found in Kota Raya and Salak. The facts indicate that public open space is a critical need for people. They kept using POS with or without sufficient services. However, a high-quality feature can support visitor's activities (Ashihara, 1981; Avila, 2001; Carr et al., 1992; GEHL Architects, 2002; Shirvani, 1985). It can make the activities more comfort and pleasant. With a minimum facility, people still took advantages of POS. It is suggested that a better facilities will attract many more visitors, thus much more community can get benefits from the POS.

\section{c. Natural elements}

The natural elements in the POS include trees, garden and grass field. Many other studies correlate these items with thermal comfort. However, this survey points out that some types of trees did not always give a significant shading, such as palmae trees. Mainly, the trees were planted in the periphery. The other natural element was the garden. This aspect relates to relaxation effects for psychological needs. In the survey, the garden was only available in three POS (Raya, Sidikalang, and Salak). Unfortunately, these POS was less active than the others.

\subsection{The public life}

The public sphere is associated with the intensity and variety of activities in POS. One of the activities that always occurs in all the POS was sports/exercising. In an active POS, the activities spread out in every part of POS, mainly in the grass field. (Figure 1). However, the sports facility was not always available. The community was doing sports in any part of POS, mostly on the grass field. Many kinds of sports could be found, such as football, basketball, volleyball, jogging or gymnastic. The other activities were social interactions and playing, particularly for children and teenagers. Generally, all ages group could be found in the POS. It can be said that, generally, the POS were successful (CABE \& DETR, 2001; Rivlin, 1994; Whyte, 1980). Most of the visitors in this POS were families that brought along their children. This was different with Medan and other POS, where the visitors was primarily the teenagers (GEHL Architects, 2002; Nasution \& Zahrah, 2014). This fact showed that POS in these small towns was the free facility for family activity. In the bigger city like Medan, this function mostly offered with charges, such as malls, cafes, theme parks and indoor playground.
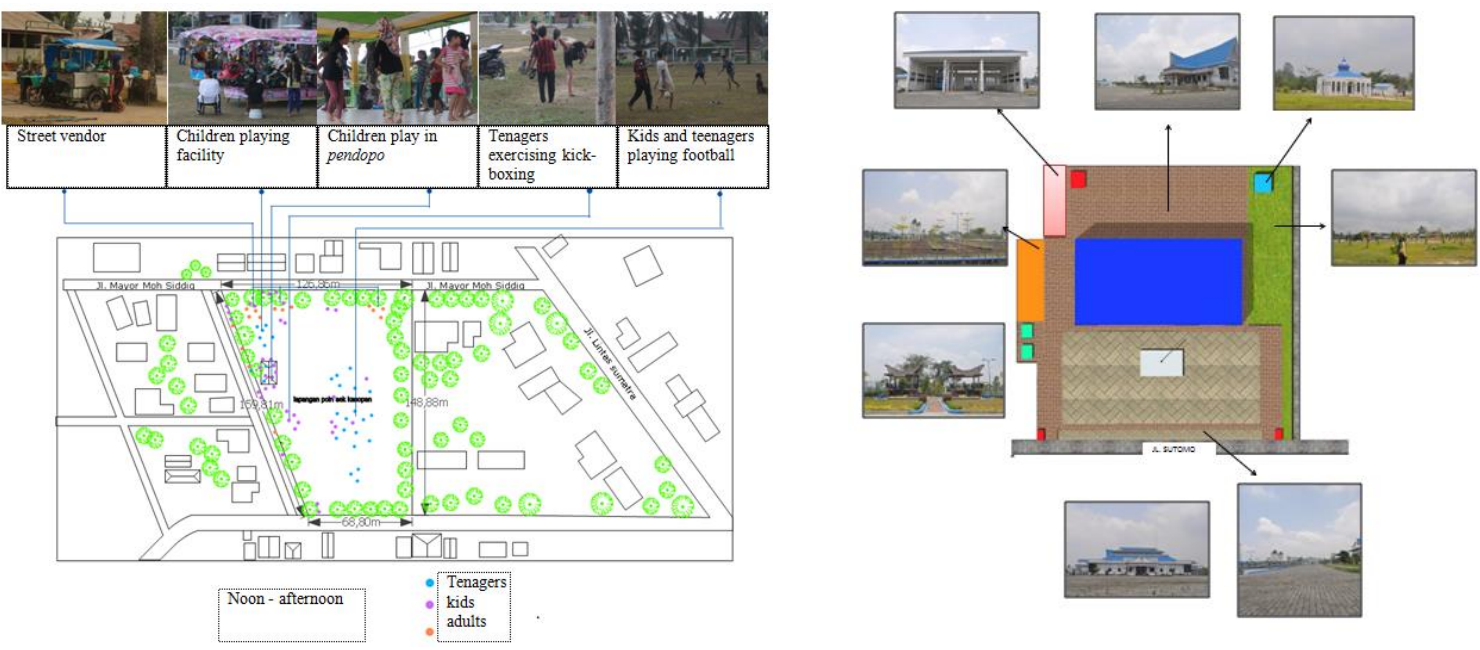

Fig. 1. Behavioral mapping of an active POS in Aek Kanopan (left) and less active POS in Raya (right) 
In average, respondents have agreed that mostly POS has functioned as the recreational area, sports/exercising, interaction, and political activity. The highest score they gave was the social function, and the lowest were the recreation function (Table 5). Based on all parks, the lowest score for functional was the POS in Panyabungan, and the highest were POS in Salak. All of the satisfaction levels had the score of below 4. Although those of unsatisfied respondents were much lesser, but the level of satisfaction yet reaches the ideal preference. The same result could be found on satisfaction with the facility in POS that also below 4. However, this perception did not become the indicator of the public life at POS. Poor perception of POS by respondents was found in Aek Kanopan and Kota Pinang, the two active POS. Otherwise, a minimum number of respondents in Raya and Salak had a better perception in POS, but the two POS were less active. The research shows that almost all the POS in Sumatra Utara were successful, indicated by the various ages and social class of visitors that did various activities (CABE \& DETR, 2001; Rivlin, 1994; Whyte, 1980). Overall, with or without a good design, more or less activity, this study has shown that POS users believed that POS has been giving a positive impact on the community quality of life (Table 7). This fact indicates that POS is needed by people. Thus, it becomes an essential urban architecture element when we believe that architecture is made for a better life.

Table 5. Level of satisfaction with the function of open space

\begin{tabular}{lcccccccc}
\hline \multicolumn{1}{c}{ Variable } & \multicolumn{1}{c}{ Open Space } \\
\cline { 2 - 9 } & $\begin{array}{c}\text { Aek } \\
\text { kanopan }\end{array}$ & $\begin{array}{c}\text { Kota } \\
\text { pinang }\end{array}$ & $\begin{array}{c}\text { Panya } \\
\text { bungan }\end{array}$ & $\begin{array}{c}\text { Rantau } \\
\text { prapat }\end{array}$ & Raya & Salak & $\begin{array}{c}\text { Sidi } \\
\text { kalang }\end{array}$ & Average \\
\hline Recreational Function & 2,66 & 3,12 & 2,43 & 3,68 & 2,40 & 4,41 & 3,00 & 3,10 \\
$\begin{array}{l}\text { Sport/exercisinng } \\
\text { Function }\end{array}$ & 3,27 & 3,41 & 2,23 & 3,96 & 4,00 & 4,49 & 3,68 & 3,58 \\
$\begin{array}{l}\text { Social/ Interactional } \\
\text { Function }\end{array}$ & 3,47 & 3,64 & 3,50 & 3,45 & 4,20 & 4,69 & 3,44 & 3,77 \\
Political Function & 3,48 & 3,63 & 2,27 & 2,96 & 4,00 & 4,28 & 2,94 & 3,37 \\
Average & 3,22 & 3,45 & 2,61 & 3,51 & 3,65 & 4,47 & 3,27 & 3,45 \\
\hline
\end{tabular}

Table 6. Perception towards function in open space

\begin{tabular}{lcccccccc}
\hline & \multicolumn{7}{c}{ Open Space } \\
\cline { 2 - 8 } \multicolumn{1}{c}{ Variable } & $\begin{array}{c}\text { Aek } \\
\text { kanopan }\end{array}$ & $\begin{array}{c}\text { Kota } \\
\text { pinang }\end{array}$ & $\begin{array}{c}\text { Panya } \\
\text { bungan }\end{array}$ & $\begin{array}{c}\text { Rantau } \\
\text { prapat }\end{array}$ & Raya & Salak & $\begin{array}{c}\text { Sidi } \\
\text { kalang }\end{array}$ & Average \\
\hline Area & 3,66 & 3,75 & 2,43 & 3,88 & 4,80 & 4,77 & 3,32 & 3,80 \\
Parking & 2,84 & 2,93 & 2,13 & 2,80 & 4,60 & 4,38 & 3,18 & 3,27 \\
Pedestrian path & 3,36 & 3,24 & 3,10 & 2,95 & 4,60 & 4,74 & 3,56 & 3,65 \\
Toilet & 1,53 & 2,10 & 1,63 & 2,48 & 4,00 & 4,21 & 2,56 & 2,64 \\
Playground & 2,79 & 3,22 & 1,70 & 3,78 & 2,40 & 4,69 & 3,29 & 3,12 \\
Sports/exercising area & 3,26 & 3,56 & 2,13 & 3,96 & 3,80 & 4,69 & 3,41 & 3,54 \\
Sitting area & 2,79 & 2,77 & 3,33 & 3,85 & 4,20 & 4,69 & 3,65 & 3,61 \\
Garden area & 2,74 & 2,58 & 2,83 & 3,58 & 2,80 & 4,85 & 3,26 & 3,23 \\
Picnic area & 2,64 & 2,35 & 2,03 & 3,07 & 1,80 & 4,54 & 2,97 & 2,77 \\
Prayers area & 3,08 & 2,08 & 1,70 & 2,67 & 3,20 & 4,26 & 2,74 & 2,82 \\
Foodcourt area & 3,12 & 2,95 & 3,30 & 3,27 & 2,20 & 4,26 & 2,53 & 3,09 \\
Food vendors area & 3,13 & 2,95 & 3,37 & 3,38 & 1,80 & 3,97 & 3,03 & 3,09 \\
Average & 2,91 & 2,87 & 2,47 & 3,31 & 3,35 & 4,50 & 3,13 & 3,22 \\
\hline
\end{tabular}


Table 7.Perception between open space and quality of life

\begin{tabular}{lcccccccc}
\hline & \multicolumn{7}{c}{ Open Space } \\
\cline { 2 - 9 } Statement & $\begin{array}{c}\text { Aek } \\
\text { kanopan }\end{array}$ & $\begin{array}{c}\text { Kota } \\
\text { pinang }\end{array}$ & $\begin{array}{c}\text { Panya } \\
\text { bungan }\end{array}$ & $\begin{array}{c}\text { Rantau } \\
\text { prapat }\end{array}$ & Raya & Salak & $\begin{array}{c}\text { Sidi } \\
\text { kalang }\end{array}$ & $\begin{array}{c}\text { Average } \\
\text { Activity affects health }\end{array}$ \\
$\begin{array}{l}\text { Being in a park making soul more } \\
\text { calm and relax }\end{array}$ & 4,93 & 3,91 & 3,20 & 4,07 & 4,20 & 4,82 & 4,32 & 4,06 \\
$\begin{array}{l}\text { Activity done in park making a good } \\
\text { social relationship within people }\end{array}$ & 4,06 & 4,11 & 3,73 & 4,05 & 4,20 & 4,74 & 4,12 & 4,14 \\
$\begin{array}{l}\text { Feeling happy being in the park } \\
\text { The park makes the city surrounding } \\
\text { better }\end{array}$ & 4,07 & 4,04 & 3,57 & 4,14 & 4,20 & 4,87 & 3,97 & 4,12 \\
Average & 4,22 & 4,29 & 3,73 & 4,02 & 4,60 & 4,87 & 4,24 & 4,28 \\
\hline
\end{tabular}

\section{Conclusion}

As an urban architecture element, public open spaces are not always planned to be comprehensive in designsurrounding condition and community needs. As the consequence, one POS of a poor design had an active utilization; meanwhile, the better one was less active. This finding is parallel with some result in other research of public open space in South East Asia that public life in public open space is not always directly related to the quality of design (Karuppannan \& Sivam, 2013; Nasution \& Zahrah, 2014). The study also found that POS in Sumatra Utara needs an adequate parking lot facility as a consequence of "vehicle dependency-habit". The community looked like do not need a pedestrian path and linkage like in the other country. However, it is recommended to apply many more pedestrian paths in the whole city space. It is necessary to educate people that the physical activity can improve health and save fuel energy. However, this study has a weakness when surveying only the people who visit POS. Further research is expected to use the household survey, in order to obtain a complete picture of how people perceived POS and its impact on quality of life.

\section{Acknowledgment}

This research was supported by Ministry of National Education of Indonesian Republic through Hibah Bersaing research grant. Thank you for all surveyors and participants for their precious contributions, particularly Urban Design Class 2016, Department of Architecture, Universitas Sumatera Utara.

\section{References}

Arifady. (2001). Skenario Pengembangan Kota Magelang. MPKD UGM.

Ashihara, Y. (1981). Exterior design in architecture. New York: Van Nostrand Reinhold.

Avila, M. I. M. (2001). Factors that Influence The Social Life and Vitality of Public Spaces In Maracaibo - Venezuela. Case Study: Plaza de la Madre and Plaza de la Republica. Virginia Polytechnic Institute and State University.

CABE, \& DETR. (2001). The value of urban design. London. Retrieved from http://www.designcouncil.org.uk/sites/default/files/asset/document/the-value-of-urban-design_0.pdf

Carr, S., Francis, M., Rivlin, L. G., \& Stone, A. M. (1992). Public space. New York: Cambridge University Press.

Curson, T., Evans, G., \& Bohrer, J. (1995). Market research survey of people using the Royal Parks: annual report 1994. Market research survey of people using the Royal Parks: annual report 1994. London: University of North London Press. 
Danisworo, M. (1988). Konseptualisasi Gagasan Dan Upaya Penanganan Proyek Peremajaan Kota, Pembangunan Kembali Sebagai Fokus. Institut Teknologi Bandung.

GEHL Architects. (2002). Public Space and Public Life City of Adelaide: 2002. Adelaide: GEHL Architects. Retrieved from www.planningsa.gov.au

Karuppannan, S., \& Sivam, A. (2013). Comparative analysis of utilisation of open space at neighbourhood level in three Asian cities: Singapore, Delhi and Kuala Lumpur. URBAN DESIGN International, 18(2), 145-164. https://doi.org/10.1057/udi.2012.34

Lakitan, B. (2002). Dasar-dasar Klimatologi. Jakarta: RajaGrafindo Persada.

Laurie, M. (1986). An introduction to landscape architecture. New York: Elsevier.

Martopo, S., Fandeli, C., Herlian, A., \& Purwanto, A. (1995). Pengaruh Ruang Terbuka Hijau Kota Terhadap Kondisi Lingkungan Sekitarnya di Kodya Yogyakarta. Yogyakarta.

Nasution, A. D., \& Zahrah, W. (2012). Public Open Space Privatization and Quality of Life, Case Study Merdeka Square Medan. Procedia Social and Behavioral Sciences, 36, 466-475. https://doi.org/10.1016/j.sbspro.2012.03.051

Nasution, A. D., \& Zahrah, W. (2014). Community Perception on Public Open Space and Quality of Life in Medan, Indonesia. Procedia - Social and Behavioral Sciences, 153, 585-594. https://doi.org/10.1016/j.sbspro.2014.10.091

Nasution, A. D., \& Zahrah, W. (2015). The Space is Not Ours, the Life of Public Open Space in Gated Community in Medan, Indonesia. Procedia - Social and Behavioral Sciences, 202, 144-151. https://doi.org/10.1016/j.sbspro.2015.08.217

Project for Public Spaces. (2000). How to turn a place around: a handbook for creating successful public spaces. New York: Project for Public Spaces.

Pudjiharta, A. . (1980). Peranan Vegetasi Dalam Menjaga Kualitas Lingkungan. Bogor: Lembaga Penelitian Hutan.

Rivlin, L. G. (1994). Public spaces and public life in urban areas. In S. J. Neary, M. S. Symes, \& F. E. Brown (Eds.), The Urban Experience: A People Environment Perspective (pp. 289-296). E \& FN Spon.

Shirvani, H. (1985). The urban design process. New York: Van Nostrand Reinhold.

Sugiyama, T., Francis, J., Middleton, N. J., Owen, N., \& Giles-Corti, B. (2010). Associations Between Recreational Walking and Attractiveness, Size, and Proximity of Neighborhood Open Spaces. American Journal of Public Health, 100(9), $1752-1757$. https://doi.org/10.2105/AJPH.2009.182006

Whyte, W. H. (1980). The social life of small urban spaces. Washington DC: Conservation Foundation. 